\title{
Protection of Agricultural Land Sustainable Food for The Realization of Food Security in The Special Region of Yogyakarta
}

\author{
Yeni Widowaty \\ Master of Law \\ Graduate Program, Universitas Muhammadiyah Yogyakarta \\ Yogyakarta, Indonesia \\ yeniwidowaty@umy.ac.id
}

\author{
Imam Oktavian Artanto \\ Master of Law \\ Graduate Program, Universitas Muhammadiyah Yogyakarta \\ Yogyakarta, Indonesia \\ imamartantyo@gmail.com
}

\begin{abstract}
The question of providing agricultural land for food is currently experiencing problems and challenges. Threats to the function of agricultural land for non-agriculture potential threaten food security. The formulations of the problem proposed include 1) how is the implementation of policies for sustainable food protection of agricultural land to realize food security? 2) how is the future concept in the sustainable food protection of agricultural land to realize food security in the Special Region of Yogyakarta? The type of research is empirical juridical, involving the primary data and secondary data. Bantul and Sleman Regencies are the research samples. The results showed that the implementation of protection of agricultural land and food in Sleman Bantul Regency had been carried out. The prevention of the conversion of agricultural land, has been carried out through Housing moratorium, housing system with infil and Limiting land cash above the village function. However, in practice the conversion of agricultural land still occurs mainly in suburban areas. The concept of future action is deemed necessary including 1) law enforcement of the perpetrators of the conversion of agricultural land and 2) conducting Integrated Agricultural Systems (IFS)
\end{abstract}

Keywords- agricultural land, food security, protection, sustainable.

\section{INTRODUCTION}

Along with the rate of conversion of agricultural land to non-agricultural land, an agricultural resource that needs to be prioritized is agricultural land, especially food agriculture. Sustainable agricultural development is associated with the important issues in development today. Sustainable agriculture is a process that utilizes agricultural resources optimally to meet the needs and welfare of today's society without sacrificing the needs and welfare of future generations.

Controlling the conversion of agricultural land through the Law of the Republic of Indonesia Number 41 of 2009 concerning Protection of Sustainable Farming Land is expected to encourage the availability of agricultural land to maintain food independence, resilience and sovereignty.

Implementation of Law No. 41 of 2009 in the Special Region of Yogyakarta was issued by the Special Region of Yogyakarta Province through Regulation Number 10 of 2011 concerning Sustainable Agriculture Food Crops. One of the reasons to issue the regulation because the distress in the conversion of agricultural land in Special Region of
Yogyakarta (Daerah Istimewa Yogyakarta) - especially in the Bantul and Sleman regions.

The area of agricultural land in Yogyakarta reduced from 85 ha in 2010 to only 62 ha in 2015. Meanwhile, Sleman district had 22,619 ha of agricultural land in 2010, and then reduced into only 21,907 ha in 2015. Likewise, in Bantul Regency 15,465 agricultural land in 2010 is also predicted to decrease into 15,225 by 2025 . Almost all regions experience a decrease in the area of agricultural land. At present the possibility of agricultural land is reduced more because in 2017 several hotels and housings were built [1].

Empirically, the most vulnerable agricultural land to function change is rice fields. This is because population density in rural areas have been dominated more by rice field agroecosystems compared to the dry land agroecosystems. Many rice fields are located close to urban areas that generally have the better infrastructure compared to dry land areas. The infrastructure development and settlement facilities, industrial estates, and so on tend to progress rapidly in flat-terraced areas, where in areas with such topography (especially in Java) the agricultural ecosystem is predominantly paddy fields [2].

In the peri-urban area, an area between urban and rural areas, some changes occur in land use with the impact on the loss of agricultural land, symptoms of commercialization and intensification of agricultural land, and decrease in agricultural production and productivity. Farmers land getting narrower due to housing and industrial land needs causes some changes in people's livelihoods for no longer being the farmer [3]

The problem of providing agricultural land for food production is currently experiencing some severe problems and challenges. The conversion of agricultural land to nonagriculture potentially threatens the sustainability of regional food security in supporting national food security. Special Region of Yogyakarta is the first area in Indonesia to have a Regional Regulation on Sustainable Food Farming Protection. Even so, socialization to the public about the regulation is still found very lacking. It is worrying that the lack of socialization will harm the owners of agricultural land that will be used as sustainable food agriculture. Various policies related to the problem of controlling the conversion of agricultural land, especially the rice fields have been made. Its implementation however is less effective for not being 
supported by adequate data and proactive attitudes from stakeholders. The lack of law enforcement against perpetrators is also a trigger for the continued conversion of agricultural land.

Effective and successful law enforcement is dependent upon three elements of the legal system: legal structure (structure of law), substance of the law and legal culture. Legal structure concerning law enforcement officers, legal substance including legislation and legal culture is living law adopted in a society [4]

This research raises 2 research questions as follows:

1. How is the implementation of the Sustainable Food Farm Protection Policy to realize food security in the Special Region of Yogyakarta?

2. What is the future concept of Sustainable Food Farming Protection in order to realize food security in Yogyakarta Special Region?

The previous study of this topic has been conducted First, conducted a research with entitled "Implementation of Land Management for Public Interest in its Relationship with Sustainable Agricultural Land Protection. The result of the research showed that the implementation of land acquisition for the construction of the Trans Java toll road was in accordance with the President Regulation No. 36 Year 2005. The compensation for agricultural land owned by residents affected by the conversion of agricultural land for the public interest was done by deliberation to determine the selling value of the tax object. However, the results of the deliberation have not yet reached the point of mutual agreement between the Land Acquisition Committees [5] Second, conducted research with entitled "Law Enforcement Against the Transfer of Agricultural Land Function to Nonagricultural Land in the City of Mataram". The results of the study showed that the policy of the Mataram municipal government in the midst of conditions of increasing function of agricultural land increased. The Mataram City Regional Representative and the executive will revise the spatial plans regulation. The revision aims to build a better city layout. The law enforcement against the conversion of agricultural land into nonagricultural land in the city of Mataram has not been effective for being influenced by juridical/legal factors such as legal substance, legal structure, and legal culture. Nonjudicial or non-legal factors include the economic factors, factor of the application of Mataram as the center of economy and services/ Mataram Metro, less assertive factor of law enforcement, rapid population growth, and another social factor [6].

\section{METHODS}

\section{A. Type of Research}

This research is a socio-legal research that is research in the form of empirical research that is oriented to the discovery of theories regarding the process of occurrence and about the process of working the law in the community or investigating the relevance of the law with other social symptoms [7].

\section{B. The Research Data}

There are two kinds of data namely primary data and secondary data. Primary Data obtained from the results of field research and interview. The interview has been conducted with the resource persons as follows:

1. Marjana, the chief of Management, and Arrangement of Land of Bantul District.

2. Ismail, S.Si. Msi, staff of the Agricultural Extension Facilities of Bantul District.

3. Rianti, staff of the Agriculture Office of Yogyakarta Special Region.

Meanwhile secondary data obtained from the legal documents, and another sources such as acts and regulations, books or literature and other documentary materials.

\section{The Locations of Research}

The research was conducted in Yogyakarta Special Region by taking locations in two districts, Sleman Regency and Bantul Regency.

\section{Method of Data Analysis}

This study is using a flow model of analysis [8] as shown in Figure 1. In more detail the data obtained from the study, both library research or field research, were processed and analyzed analytically critically and presented in qualitative descriptive. The data analysis stage is an important step in a research process.

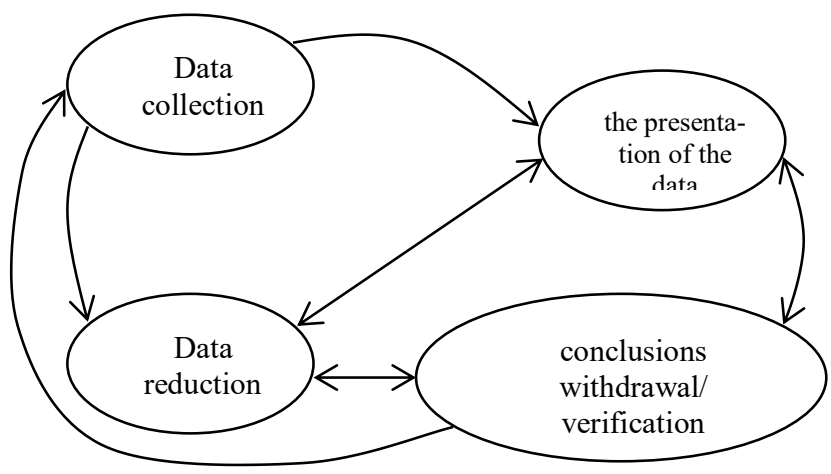

Figure 1. Flow model fo analysis

In connection with a legal research that wants to find answers to legal issues that divert to the issue of protection against victims, it is important to do an analysis with not only the emphasis on the major premise derived from formal and material law, but the premise is also sought from existing theories, all of which directly or indirectly base their truth on the data obtained through studies with induction logic [9].

\section{RESULTS AND DISCUSSION}

\section{A. Equations The Implementation of the Sustainable of Food Agricultural Land in Realizing the Food Security in Yogyakarta Special Region}

The implementation of Land Protection for Sustainable Food Agriculture (PLP2B) to Achieve Food Security in the Special Region of Yogyakarta is carried out through several program activities, namely planning, determining, developing, utilizing, coaching, controlling, supervising, 
community participation, financing, protection and empowerment of agriculture, investigation, criminal.

Based on the schedule, the Implementation of Sustainable Food Agricultural Land Protection in DIY as stated in the Road Map Implementation of Protection of Agricultural Land Sustainable Food (PALSF) in DIY is presented at table 1.

Table 1. The Land Protection for the Implementation of the Agriculture Food Sustainability

\begin{tabular}{|c|c|c|c|c|c|c|c|}
\hline $\mathrm{N}$ & Programe & Priorit & & & Time: & & \\
\hline & $\begin{array}{c}\text { The } \\
\text { activities of } \\
\text { PLP2B }\end{array}$ & & 2016 & 2017 & 2018 & 2019 & 2020 \\
\hline 1 & Planning & I & $\mathrm{V}$ & $\mathrm{V}$ & $\mathrm{v}$ & & \\
\hline 2 & $\begin{array}{c}\text { determinatio } \\
n\end{array}$ & I & & & $\mathrm{v}$ & $\mathrm{v}$ & $\mathrm{v}$ \\
\hline 3 & financing & $\mathrm{I}$ & $\mathrm{V}$ & $\mathrm{V}$ & $\mathrm{V}$ & $\mathrm{v}$ & $\mathrm{V}$ \\
\hline 4 & supervision & I & & & & $\mathrm{V}$ & $\mathrm{V}$ \\
\hline 5 & $\begin{array}{c}\text { community } \\
\text { participation }\end{array}$ & II & $\mathrm{v}$ & $\mathrm{v}$ & $\mathrm{v}$ & $\mathrm{v}$ & $\mathrm{v}$ \\
\hline 6 & development & III & & & & $\mathrm{v}$ & $\mathrm{V}$ \\
\hline 7 & $\begin{array}{c}\text { the } \\
\text { utilization of }\end{array}$ & III & & & & $\mathrm{v}$ & $\mathrm{v}$ \\
\hline 8 & coaching & III & & & & $\mathrm{V}$ & $\mathrm{V}$ \\
\hline 9 & $\begin{array}{c}\text { protection } \\
\text { and } \\
\text { empowerme } \\
\text { nt of farmers }\end{array}$ & III & & & & $\mathrm{V}$ & $\mathrm{v}$ \\
\hline 10 & control & IV & & & & $\mathrm{V}$ & $\mathrm{V}$ \\
\hline 11 & investigation & $\mathrm{V}$ & & & & $\mathrm{V}$ & $\mathrm{V}$ \\
\hline 12 & criminal & V & & & & $\mathrm{v}$ & $\mathrm{v}$ \\
\hline
\end{tabular}

Source: Road Map PALSF Implementation in DIY 2016

Sustainable Food Farm (SFF) policy is a policy that has been stipulated in Law No. 41 Year 2009. This regulation has been running for approximately 9 years. However, the way of the implementation of SFF is interesting to evaluate. Whereas in DIY the arrangement is regulated in Yogyakarta Special Region Province Regulation Number 10 Year2011 concerning Protection of Sustainable Food Agricultural Land. This evaluation is aimed at knowing the implementation of SFF in DIY and the problems in its implementation.

The evaluation of the SFF implementation in the area is an inseparable part of the SFF program. SFF evaluation is included in the research and supervision aspects. The results of this evaluation can provide input on the implementation of SFF in the region. The aspects evaluated include all aspects started from planning, implementing, monitoring, to community participation in SFF. Theoretically, there are three approaches that can be taken in controlling the transfer of agricultural land functions: (1) regulation, (2) acquisition and management, and (3) incentives and charges.

There are several things that have the potential to become obstacles to the implementation of regulations regarding land conversion control, namely: (1) contradictory policies; (2) Limited policy coverage; and (3) Constraints to planning consistency. In its implementation the government has issued a policy that prohibits land conversion, but on the other hand raises economic and industrial policies that encourage the conversion of agricultural land. The scope of the policy (regulation) is only limited to companies / legal entities that will use the land and / or change the land use function
Changes made by individuals have not / are not covered by the regulation, while the reality of land conversion carried out by individuals is estimated to be quite broad. On the other hand, the consistency of planning is an obstacle because the Regional Spatial Plan and location permits as the control instruments have not completely prevented the conversion of agricultural land into non-agricultural land.

From the results of research, Bantul and Sleman districts have carried out several policies to overcome the conversion of agricultural land to non-agriculture.

\section{1) Bantul Regency}

The policies related to Sustainable Food Farming Protection in Bantul District which is to prevent the conversion of agricultural land, such as:

\section{a) Housing moratorium}

Housing moratorium is a limitation in housing construction. In Bantul Regency it has been regulated in Circular Number: 648/02283 concerning the control of housing construction for Banguntapan, Kasihan, Sewon, Pleret and Bantul Subdistricts. This is because these five sub-districts have the most prevalent housing developments and are the buffer zones of Yogyakarta City, especially the Banguntapan, Sewon, and Kasihan Districts, which are located directly adjacent to the City of Yogyakarta. The sub-district has a very strategic location and fast access to reach the centers of economic activity, education, services, and so on. In addition, in the three sub-districts namely Banguntapan, Sewon, and Kasihan Sub districts at this time can be stated to be in an alarming condition for land conversion. The conversion of land functions in Bantul Regency on average is approximately 35-40 hectares per year, which is dominated for the construction of residential houses, as well as trade and services. In these three subdistricts, land conversion in Bantul has occupied $80 \%$, and highest area of land conversion is found in Banguntapan Sub-district.

\section{b) Protection of Sustainable Food Farming Land}

Stated in Law Number 41 Year 2009 concerning Protection of Sustainable Food Agricultural Land in Article 1 point 3 , sustainable food agricultural land is a field of agricultural land that is determined to be protected and developed consistently in order to produce staple food for national food independence, resilience and sovereignty. Furthermore, in Article 5 it is stated that this sustainable food crop land includes irrigated land, tidal and non-tidal swamp reclamation land and non-irrigated land.

Based on Article 9 paragraph (1) and (2) Special Region of Yogyakarta Regulation Number 10 Year 2011 concerning Protection of Sustainable Food Agricultural Land stipulated, the Special Region of Yogyakarta Province has a sustainable food agriculture area of 35,911.59 Ha, while Bantul Regency has the area of sustainable food agriculture targeted of 13,000 Ha. The regulation regulates the protection and development of sustainable food agricultural land to maintain national food security. 
To support the success of the program as an effort to strengthen agricultural productivity, especially rice in the Bantul Regency as a food buffer pillar, it is necessary to ensure that rice fields are called sustainable food agriculture. Determining the regional development policies is by paying attention to the potential of land that must be maintained and may be converted to regional development.

\section{Sleman Regency}

Based on the results of in-depth interviews that have been carried out on several policies implementing organizations, it can be seen that the agencies in general agree with the Sustainable Food Agricultural Land Protection Policy. The reason for the agreement was due to the Sustainable Food Agriculture Land Protection Policy already stated in the Law and legally binding. Thus, it must be implemented.

Practices related to Sustainable Food Agriculture Land Policy have not specifically been carried out by relevant agencies due to the lack of specific locations designated as Sustainable Food Agriculture Land and the absence of local regulations or district-level planning products related to the policy. The current practice of the agency is in the form of efforts to protect agricultural land. Some of the efforts have been made by the government including by helping farmers to certify agricultural land on the condition that if the land has been certified, it cannot be converted; the process of developing rice fields where the permits are increasingly tightened, and the installation of agricultural plots.

Most of land owners know that it is not permissible to build in the rice fields, but in practice there are many still transferring the function of agricultural land into residential areas or hotels. At present, the average productivity of rice plants in Sleman Regency reaches 6.2 tons of milled dry grain per hectare. With the depreciation of agricultural land of more than 100 hectares per year, the decline in grain production could reach 6,200 tons of paddy in each year.

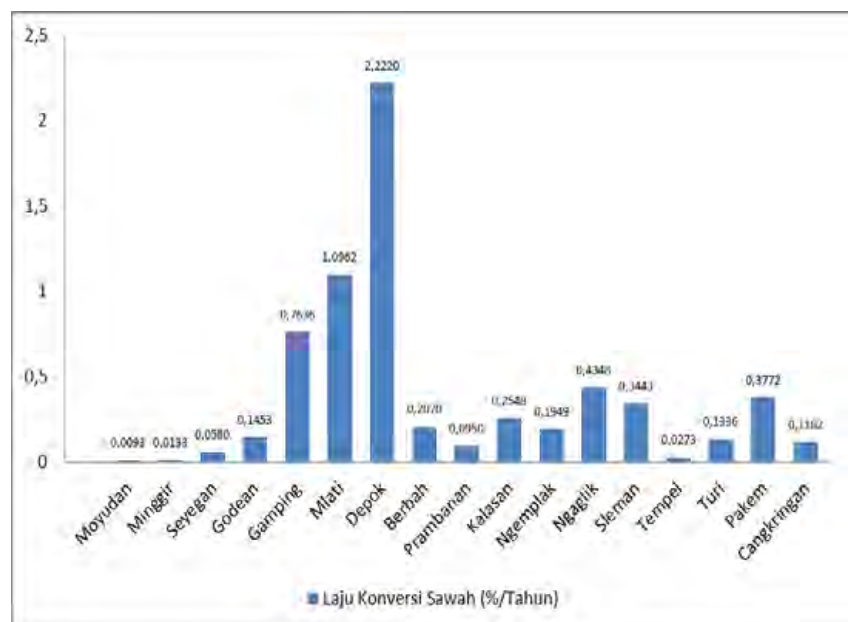

Figure 2. The Speed of Land Conversion in Sleman Regency Source: Central Bureau of statistics 2008-2013

Planning related to SFF in Sleman Regency is also listed in the Appendix of Sleman Regency Regional Spatial Plan 2011-2031 involving Agriculture, Fisheries and Forestry Services, Regional Land Control Services, and Water and Mineral Energy Resources Service. Sleman Regency's LPPB area is $12,377.59$ hectares as stated in Special Region of
Yogyakarta No. 10/2011 on the determination of the area, the process of which involves the Sleman Regency; so that it is expected in accordance with the amount of land planned by Sleman Regency as SFF. The Sleman Regency Government stated that they have not dared to socialize that these villages are SFF but still called the Agricultural Strategic Areas.

Based on the data of paddy conversion rate per subdistrict in Sleman Regency in the picture of the Rice Field Conversion Rate diagram of Sleman Regency per District, it can be seen that the conversion rate in the Strategic Agriculture Area is of little value, namely Moyudan District at $0.0093 \%$ / year, District Minggir at $0.0133 \%$ /year, Seyegan sub-district at $0.0580 \% / y e a r$; and Godean sub-district affected by urban development at $0.1453 \%$ / year.

Districts included in the Agricultural Strategic Areas are Minggir, Moyudan with the lowest productivity value of 61 $\mathrm{Kw} / \mathrm{Ha}$, Seyegan with $62 \mathrm{Kw} / \mathrm{Ha}$, and Godean District with $63 \mathrm{Kw} / \mathrm{Ha}$. The highest productivity value of $65 \mathrm{Kw} / \mathrm{Ha}$ was found in Ngaglik District, Depok, and Berbah. Based on these data, it has been found that rice productivity in the District Strategic Agriculture Area is lower than that of other districts in Sleman Regency.

In controlling agricultural-land the local governments should also refer to the principle of sustainable development. The application of the principles of sustainable development in all sectors and activities become the main requirements to be internalized into policies and regulations in order in which future generations will not inherit the damaged and polluted environment [10].

In the law of welfare, the state is responsible for realizing the welfare of its people. In this case, as a starting point and an important foundation in the implementation of state life [11]. Refers to Mac Iver, there are three main functions of the state, namely: order; protection and maintenance and development" [12].

\section{B. The Concept of Sutainable Protection of Food Farming Land to Realize Food Security in Yogyakarta Special Region in the Future}

To overcome the rate of land conversion, the Local Regulation of Special region of Yogyakarta Number 10 of 2011 is concerning Sustainable Protection of Food Agriculture Land. This regulation has been issued with the following objectives: (1) to protect the area and food cropland in a sustainable manner; (2) to guarantee the availability of sustainable agricultural food land; (3) to realize independence, resilience and food sovereignty; (4) to protect the ownership of farmer food owned by farmers; (5) to increase the prosperity and welfare of farmers and the community; (6) to improve the protection and empowerment of farmers; (7) to increase the provision of employment for life; (8) to maintain ecological balance; and (9) to realize the agricultural revitalization

It is specifically explained in the regional regulation concerning areas including land targets and sustainable food land reserves. The land of sustainable food agriculture reserves includes abandoned land, conversion of forests to food crops, and marginal land areas. The development and response of the district level SFF regulation is so diverse. This Regional Regulation has been followed up by Gunungkidul Regency by issuing Regional Regulation 
Number 23 of 2012 concerning Sustainable Protection of Food Agriculture Land.

Furthermore, the DIY Regional Government is developing the Protection of Sustainable Food Agriculture Land through the optimization of food land, including: a. Intensification of food agricultural land by increasing soil fertility through fertilization, improving the quality of animal feed and/or fish, improving the quality of seeds and/or seeds, prevention, handling pests and diseases, developing irrigation, developing agricultural innovation, agricultural extension, and/or guarantee access to capital. b. Extensification of food crop land by utilizing marginal land, utilization of abandoned land, land use under annual stands, and c. Diversification of food crop land by planting patterns, intercropping; and / or integrated farming systems.

In the context of the acceleration of the Sustainable Food Farming Land program based on Regional Regulation No. 10 Year 2011, the provision of incentives is also provided with the following schemes: (1) land and building tax relief; (2) development of agricultural infrastructure; (3) utilization of research results and development of superior seeds and seeds; (4) ease in accessing information and technology; (5) facilitation of facilities and infrastructure for agricultural production; (6) guarantee of issuance of certificates of agricultural food land through sporadic and systematic land registration; and / or; (7) awards for outstanding farmers.

Some special notes in SFF's activities include exceptions to banning and criminality. The prohibition of the conversion of sustainable food agriculture land, except "land acquisition for public interest and natural disaster". The existence of a criminal threat (Article 46-48) pursuant to Regional Regulation Number 10 of 2011: (a) individuals / individuals who transfer agricultural land are subject to a maximum of 5 years imprisonment and a maximum fine of IDR.5 billion; and (b) legal entities/companies /corporations that transfer agricultural land, their executives are sentenced to 2-7 years imprisonment and a fine of IDR 2 billion-7 billion. Furthermore, the determination of the area of sustainable land area must also refer to the Regional Regulation Number 2 of 2010 concerning the Regional Spatial Planning of the Province of DIY for 2009-2029.

With the shrinking condition of agricultural land, the future concept of agricultural business can be directed from the cultivation of agricultural production for consumption into cultivation for seed production. With the same area of seed production business, it can produce higher income compared to the cultivation of agricultural production. The regulation of the Governor of Special Region of Yogyakarta Number 76 Year 2015 refers to the facilitation for the Seed Center "Jogja Benih" that involves organizing and implementing the seed centers. The seed center is directed to facilitate the external activities of Jogja Seeds such as partnerships, promotions, information.

Provision, and infrastructure support. The implementation meanwhile is directed to facilitate internal activities in the form of institutional strengthening and improvement of Human Resources.

Ideally, the prevailing regulations give reformulating the sanctions firmly on the perpetrator. Therefore, law enforcement must be executed explicitly. How the Enforcement ruling? Using theories from Friedman [14], as follows: legal structure, legal substance, and legal culture.
First, Legal Structure. Agency/ service provider for building construction permits hotel /home stay /boarding house /apartment should be rejected if it does not comply with the filing plan of spatial districts/ city

Second, Legal substance. To limit the function of the switch from agriculture to industrial or residential plan review is required, then the spatial area of the provinces, districts, and cities. Besides, the completion of the drafting of the plan of Spatial Detail in the revised Law No. 26 Year 2007 concerning Spatial required to plan Spatial Detail in the form of local regulations

Third, Legal Culture. Community awareness (employers) at least will be the significance of productive agricultural land. In addition, the ambitious owners of capital resulted in the depletion of farmland.

Other strategies that can be reached are related to the ability to minimize the dependency of farmers, provide a decent income guarantee, guarantee sustainable farmer, a good welfare and tend to be independent. Therefore, things that have to be met in order for the peasant landholders are not easily to let go of or to sell their land. Thus, the land remains sustainable and the function of the land can be controlled.

One of the alternatives could be developed for such purposes i.e. development of Integrated Farming System (IFS). The development of this agricultural system is more directed at rural areas or if certain modifications can be developed in urban areas

Integrated Farming System (IFS) is a system of management (enterprises) that combines the components of farming, such as plants, animals and fish in a unified whole. Another definition states that IFS is a system of management of crops, livestock and fish with its environment to produce an optimal product and its nature tends to be closed against the outer input.

This system will significantly impact positive impact and meet the criteria of sustainable agricultural development due to organic-based and developed/directed based potential local (local resources). The purpose of the application of the system is to suppress the minimal possible input from the outside (low input/ input) so that the negative impacts can be avoided, and everything is possible and sustainable [15].

\section{CONCLUSION}

1. The implementation of the protection of agricultural land sustainable food to realize the food security in Special Region of Yogyakarta in the subdistricts of Bantul Regency and Sleman Regency has been done. To prevent the control of the functions of agricultural land, some of the efforts that have been undertaken include:

a) Moratorium on housing devoted to a particular sub district to reduce industrial and residential development.

b) System for housing with the infil.

c) Limit land cash over the function of the village. However, in practice over function of food agricultural land still occur especially in suburban areas of the city as a buffer. 
2. The concept of the future for the protection of agricultural land sustainable food to realize food security actions need to be performed as follows.

a) Strict enforcement by the authorities against the perpetrators of the switch function agricultural land for residential or industrial purposes.

b) conducted Integrated Farming System (IFS) in the form of system management (enterprises) that combines the components of farming, such as plants, animals and fish in a unified whole.

\section{REFERENCE}

[1] Badan Pusat Statistik Yogyakarta, 2007

[2] balittanah.litbang.deptan.go.id, "Konversi Lahan Sawah ke Penggunaan Nonpertanian dan Dampak Negatifnya", 2007. [Online]. Available: http://balittanah.litbang.pertanian.go.id/eng/dokumentasi/prosiding/mfl p2001/sumaryanto.pdf?secure=true. [Accessed: 23-Jun-2018]

[3] H. S. Yunus, Dinamika Wilayah Peri-Urban Determinan Masa Depan Kota, Pustaka Pelajar, Yogyakarta, 2008

[4] L. M. Friedman, Sistem hukum Perspektif Ilmu Sosial, Nusamedia, Jakarta, 1984

[5] S. P. Riko, "Pelaksanaan Pengadaan Tanah untuk Kepentingan Umum dalam Hubungannya dengan Perlindungan Lahan Pertanian Berkelanjutan", Master Thesis. Universitas Diponegoro. 2010.

[6] B. Burdatun, "Penegakan Hukum Terhadap Alih Fungsi Lahan Pertanian Menjadi Lahan Non Pertanian Di Kota Mataram”, J. Kaj. Huk. dan Kead. Vol. IV, No. 3, pp. 454-466, December 2016

[7] R. Atmasasmita, Perbandingan Hukum Pidana Kontemporer, Bandung: PT Fikahati Aneska, 2009

[8] M. B. Miles and A. M. Huberman, Analisis Data Kualitatif, UI Press, Jakarta, 1992, pp. 19-20

[9] S. Wignjosoebroto, Disertasi Sebuah Pedoman Ringkas Tentang Tatacara Penulisannya, Sociology Laboratory, Faculty of Social and Political Sciences, Universitas Airlangga, Surabaya, 2007

[10]Y. Widowaty, "Penegakan Hukum Terhadap Alih Fungsi Lahan Pertanian Menjadi Tempat Hunian dan Perhotelan di Yogyakarta", Paper presented in a seminar on collaboration between Master of Law Universitas Muhammadiyah Yogyakarta and Master of Law Universitas Udayana in Yogyakarta August 5, 2017

[11]S. Bethan, Penerapan Prinsip Hukum Pelestarian Fungsi Lingkungan Hidup Dalam Aktivitas Industri Nasional Sebuah Upaya Penyelamatan Lingkungan Hidup dan Kehidupan Antar Generasi, Alumnni, Bandung, 2008

[12]B. Mustafa, "Sistem Hukum Indonesia Terpadu", Citra Aditya Bakti, Bandung, 2003

[13] Y. Widowaty, "Konsep sustainable development sebagai bentuk perlindungan terhadap korban tindak pidana lingkungan hidup", Jur. Med. Huk., Vol. 19, No. 2, 2012

[14]G. S. Samidjo, Sistem Usaha Tani Terpadu, Keunggulan dan Pengembangannya, Workshop on Integrated Agricultural System Development, Department of Agriculture of the Special Province of Yogyakarta, December-2009 